\title{
Terrorist Deradicalization Programs in Saudi, Yemen and Malaysia
}

\author{
Mohd Mizan Aslama*, Siti Zubaidah Abu Bakar ${ }^{\mathrm{b}}$ \\ aSchool of Human Development and Techno-Communication, Universiti Malaysia Perlis \\ bIslamic Civilization Academy, Faculty of Social Sciences and Humanities, Universiti Teknologi Malaysia \\ *Corresponding author:m.mizan@unimape.edu.my
}

\author{
Article history \\ Received: 2019-06-18 Received in revised form: 2019-11-04 Accepted: 2020-01-01 Published online: 2020-02-29
}

\begin{abstract}
Terrorist Deradicalization is advancing subject of scientific study that lacks universally accepted definition. It is presently understood as efforts that attempt transform attitudes and behaviors of former terrorists so they reject violence as a tool to achieve ideological, religious or political goals that threaten national security and life or cause political and economic instability. Saudi Arabia Yemen and Malaysia-have deradicalization programs called Al-Ha'ir, Al-Hitar and Pemulihan, respectively, that are based on re-education and rehabilitation. Re-education components focus on correcting political and religious misconceptions, and rehabilitation provides a thoroughgoing monitoring system after inmate release. Government sponsored de-radicalization modules are designed to rehabilitate detained militants by addressing personality flaws and providing carefully structured reconstructive efforts. The authors describe methods used, which include modular themes such as holistic personality, self-reflection, social skills, criminal behavior, spirituality, Islamic consideration, security and psychology.
\end{abstract}

Keywords: Counterterrorism, deradicalization, extremists, jihadists, rehabilitation, revolution, terrorism 


\subsection{INTRODUCTION}

The Deradicalization is new area of study that lacks a universal definition. However, some researchers have classified radicalization as follows: 1) Violent Radicalization emphasizing the pursuit or acceptance of violence to attain specific goals; and 2) General Radicalization, emphasizing the pursuit or acceptance of far-reaching social changes that may or may not constitute: (a) danger to democracy, or (b) involve threats or the use of violence to attain specific goals (Veldhuis \& Staun, 2009). Aslam, M.M. (2016) outlined four stages of radicalization: preradicalization; self-identification; indoctrination; and action; similar to Silber and Bhatt's (2007) pre-radicalization, self-identification, indoctrination, and jihadization.

Radical ideologies exist that require remedies that mitigate and/or curb their menace as essential for social stability and peaceable social integration. The UN, European Union and ASEAN have a strategy called "Countering Violent Extremism" (CVE), which has been designed to counter threats and protect regions that require deradicalization. Such measures include preventive and corrective approaches using legal implementations and civil organizations. The goal is to create an unsympathetic environment that disfavors terrorist operatives and which isolates them from potential support networks.

Recent developments reveal the global terrorist challenge is a major security issue that preoccupies most countries regardless of locale or size. The major exponential force that exacerbates this menace is ideology that gives spurious license for savage behaviors. Dealing with ideology is always an uphill task given experience with fascism and communism. Current concerns are how to deal with detrimental effects on social harmony that threaten the entire world. Governments must therefore effectively address the problem to prevent its spread.

Terrorism depends on what motivates the human ego. Those who embrace extremist ideals are in a state of denial and cannot agree with contrary opinions. Hence, they tenaciously eschew opposing views and subscribe only to scholars (ideologues) with whom they share a school of thought. A key problem among Muslim terrorists is an extremist narrative focused on 'fatwas' issued by errant scholars and imams. Terrorists also require political, social and religious motives to, accordingly, commit lawless deeds to achieve a hegemonic goal. Principle Islamist terrorists share the primary objective of establishing an Islamicate or Caliphate (Daulab Islamiyyah) as advocated by ISIS, Al-Qaeda, Jemaah Islamiyyah (JI), Kumpulan Militan Malaysia (KMM), Jemaah Anshorut Taubid (JAT), the Abu Sayyaf Group (ASG) and others (Mizan, 2016).

Deradicalization programs have proven effective and will be needed as long as radical ideologies threaten national stability and peaceful social integration. Deradicalization requires long term efforts by various private and government agencies whose strategic initiatives engage the community to prevent ideological spread and extremist support networks. An effective deradicalization program thus builds social resilience and avenues for informed rehabilitation and reintegration. Community engagement remains crucially instrumental as 1) a preventative force that disengages terrorists from the consideration of violent activities; 2) and serves a rehabilitative function that addresses misinformation under which radical ideologies flourish. Detainees are instilled with appropriate defense mechanisms and taught universal values to prevent psychological manipulation by terrorist handlers. Empirical evidence supports these rehabilitation efforts with successful programs that focus on ideological, religious, educational, vocational, social, creative and psychological issues. 


\subsection{DERADICALIZATION}

Violent extremists destroy lives, devastate families and communities and cause destruction of land and livelihood; they sow seeds of intercommunal suspicion, intolerance and vengeful retaliation; all of which contribute to global insecurity and instability. These activities also affect Southeast Asia. Despite increased security, surveillance, monitoring and numerous counterterrorism programs, the terrorist problem shows no signs of abatement and seems to increase year on year. While terror plots have been foiled and radicals channeled into deradicalization programs, countless young people remain vulnerable to extremist propaganda via social media. In Southeast Asia, we are particularly concerned about home-grown terrorists radicalized both on- and offline.

Issues related to terrorists and extremists, particularly ISIS (Daesh), have opened a new chapter in the global perspective of Islam and have led to Islamophobia. Daesh's ideology directly causes violence that is incompatible with authentic Islam. Nonetheless, disillusionment within the Muslim community quickened the production of ISIS ideology. Hence, understanding this and matters of genesis are necessary for all concerned, which is everyone. With such an understanding, elements of malice that infiltrate society can be overcome and eliminated.

Deradicalization is a process of changing attitudes and behaviors of former terrorists toward violence as an ideological, religious or political tool because it needlessly threatens life and national security as well as political and economic instability. According to Ashour (2015), it is "a process though which a radical group reverses its ideology and de-legitimizes the use of violent methods to achieve political goals while moving towards an acceptance of gradual political and economic changes within a pluralistic context."

Deradicalization is a new impetus that returns former militants to normal lives by teaching them to adhere to a religion that emphasizes 1) the oneness of God; 2) faith in things unseen; 3) moderation in all things; 4) encourages good deeds; and 5) shuns evil by rewarding its followers with heaven on the day of judgement as promised by God. All of which oppose ideologies rooted in radical teachings that encourage violence and threaten lives and livelihoods of innocent people with cruelty in deference to the interests and aspirations of unscrupulous individuals.

Neumann (2010) explains that it is important for society to accept and reintegrate former terrorists to determine whether or not de-radicalization programs are successful. After deradicalization, former terrorists, like ex-prison inmates, find it difficult to rejoin public life due to the fear they will relapse or still nurse a militant private agenda. Public reluctance reflects the harsh difficulty faced when trying to disengage individuals who live in hostile and troubled areas, especially those who live in democratic societies like Australia or Great Britain.

\subsection{A COMPARATIVE METHOD}

The This study focused on deradicalization initiatives in Saudi Arabia, Yemen and Malaysia that counter violent extremism (CVE) with approaches to rehabilitation. By building wide support networks, each government gathered volunteers from various agencies and NGOs to engage the community. Seven component modules for full rehabilitation were implemented and are considered essential to counter-terrorism efforts in all three countries (Figure 1). 


\subsection{Modes of Rehabilitation}

Seven areas of human experience require rehabilitation. Empirical evidence allows slightly different approaches to factors that engender violence depending on available resources and regional recommendations. The Saudi strategy (al-Ha'ir), is described as "correctional rehabilitation intended to develop knowledge and behavioral skills through a set of programs delivered by advisors specialized in different areas of related sciences." The al-Ha'ir center offers 4-to-6-month programs that include modules in psychology, sociology, history, art therapy, self-development and online engagement. The government's voluntary program is run under the Home Affairs Ministry. Qualified scholars are hired to enter online chat rooms to discuss Islam with users, which program caters to those seeking clarification of religious knowledge where, for example, they might discuss the dangers of takfiri concepts of apostasy.

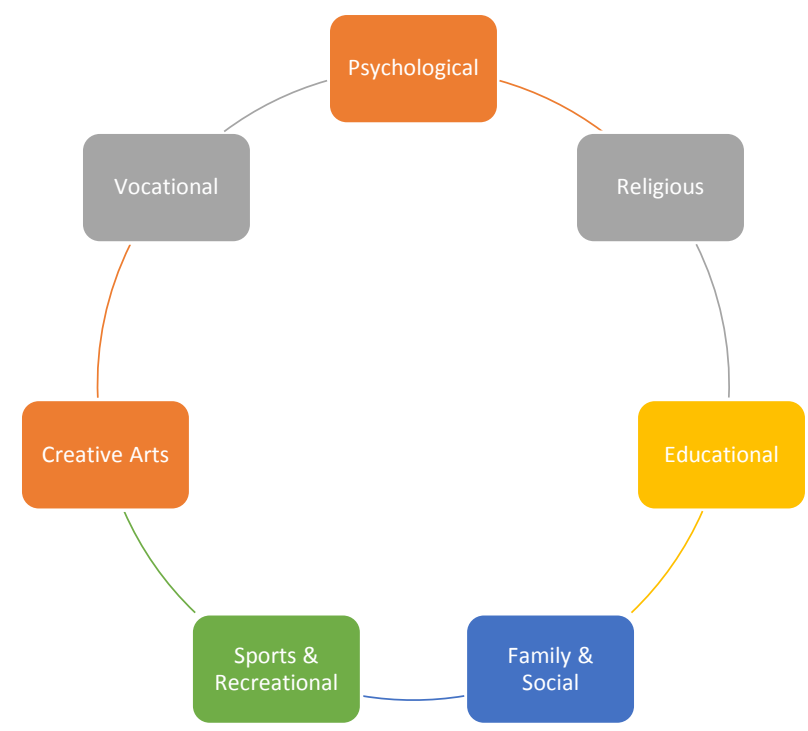

Figure 1. Modules for Deradicalization (Aslam, 2018).

Each state has different concerns that help shape respective deradicalization frameworks and content. The Yemeni government's al-Hitar is a multi-faceted program that works closely with private sectors to facilitate terrorist rehabilitation. They have hundreds of Syrian and Iraqi exterrorist alumni; convicts who were rehabilitated and reintegrated with society as productive citizens. Al-Hitar has three major components: psychological, religious, and social. Throughout detention, detainees are regularly seen by psychologists who provide counselling and assess their ability to cope with stress. An inmate's reasoning framework is continually assessed for proclivities towards hatred, violence and susceptibility to radical influences. Trained psychologists also assess behavioral and cognitive status throughout rehabilitation.

Table 1. Comparative Global Deradicalization Programs in select countries (Aslam, 2017).

\begin{tabular}{|c|c|c|c|c|c|c|c|}
\hline Country & 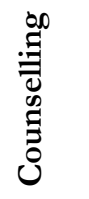 & 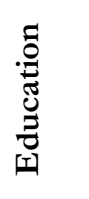 & 胥 & 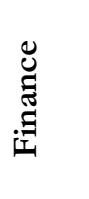 & $\begin{array}{l}\frac{\vec{d}}{0} \\
\stackrel{0}{0} \\
\dot{\infty}\end{array}$ & 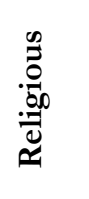 & $\frac{\mathscr{\Xi}}{\tilde{E}}$ \\
\hline Malaysia & / & I & / & / & / & / & \\
\hline Indonesia & / & & / & / & / & & \\
\hline
\end{tabular}




\begin{tabular}{|c|c|c|c|c|c|c|c|}
\hline Singapore & / & / & / & & & I & \\
\hline Thailand & / & & & & & & \\
\hline Yemen & / & & & & / & / & \\
\hline Saudi Arabia & / & / & / & / & / & I & / \\
\hline Germany & / & & I & & & & \\
\hline Great Britain & / & & & & / & / & \\
\hline
\end{tabular}

Table 1 above shows the seven main components being used in deradicalization globally. The Kingdom of Saudi Arabia is the only country that use all of the components in their rehabilitation program which is counselling, education, family, finance, society, religion and online. Malaysia ranked second in using all of the elements in their deradicalization programs except online approach. Germany, is the country that use least components which is only counselling and family approach. However, one common similarity can be seen in counselling approach throught all of the selected country as showed above.

Malaysia's deradicalization initiative was introduced through its Religious Rehabilitation Program and is based on reeducation and reintegration. The reeducation component focuses on correcting political and religious misconceptions. Rehabilitation employs a detailed monitoring system after release from the program (Noor \& Hayat, 2009). Family members are engaged and also receive financial support while militants are in detention. After release, militants are assisted with social reintegration. The entire process contributes a better understanding of deradicalization for all parties concerned and this knowledge seeps into communities where needed.

The Royal Malaysian Police (RMP) are responsible for conducting deradicalization programs. After arrest, detainees are taken to RMP Special Branch in Bukit Aman, KL for interrogation. The quality of information obtained is assessed and processed, after which follows a minimum detention period of two years under ISA. ISA has since been replaced by POTA and SOSMA. Depending on information provided, which can lead to more arrests, particularly early on in the process, detainees are confined by a Restriction Order after release. Some may be released unconditionally. Counter terrorist strategies are also implemented by government agents and agencies in cooperation with RMP Special Branch. These include the PM's office, the department of Islamic Development, and other relevant institutions.

According to Malaysia's Inspector-General of Police (IGP) Datuk Seri Muhammad Fuzi Harun, and the RMP Special Branch Officer, DCP Dato Aton Khan Mydin Pitchay, their deradicalization and rehabilitation programs have shown positive outcomes with a near $95 \%$ nonrecidivist success rate. Most released detainees have been successfully reintegrated with mainstream society, leaving only a hard core $5 \%$ who return to their old ways. Special Branch directives are such that a rehabilitation period must comply with legal provisions under the Prevention of Crime Act (POCA) and Prevention of Terrorism Act (POTA) as what is called a 'Protection Order'. This is a bid to avoid relapses that could jeopardize national security. The provision is also used to provide as much support as is reasonably possible for detainees and their families. 


\subsection{Deradicalization Model}

Malaysia launched its deradicalization model by attempting to reconstruct detainee personality traits. Areas emphasized are holistic personality, self-reflection, social skills, criminal behaviour, spirituality, Islamic consideration, security, and psychology. Yemen and Saudi Arabia have implemented similar models (Figure 2) with seven key aspects (Gunaratna \& Ali, 2015; Gunaratna \& Hussin, 2018)). However, the Malaysian approach is broader since it also covers spirituality and genuine interpretations of jihad, wasatiyyah (moderation) and faith in its inmate and community based programs. This highly effective approach should be considered for implementation in the UK.

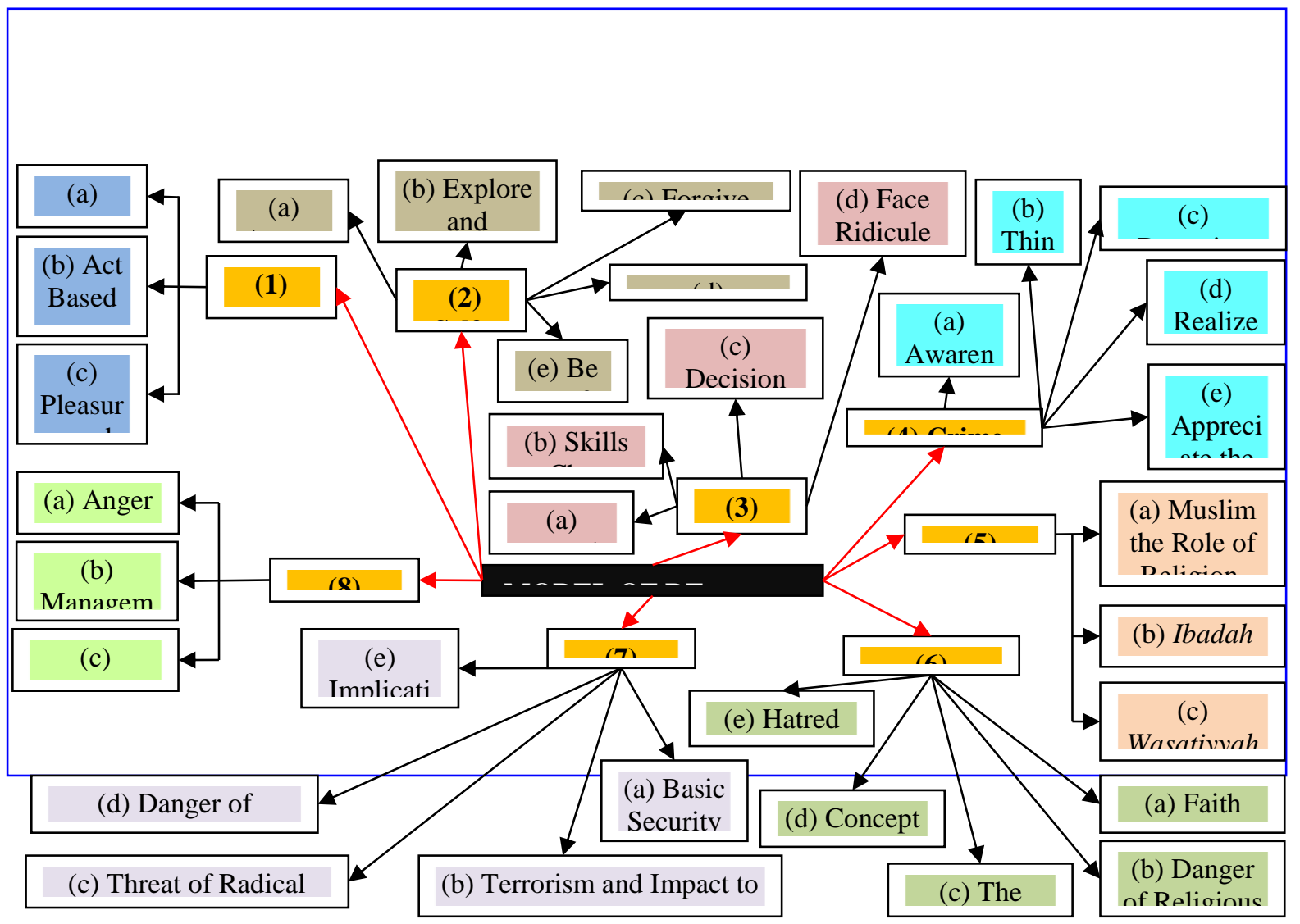

Figure 2. Deradicalization Module (Aslam, 2018).

\subsection{CHALLENGES CONFRONTED REHABILITATION

Although rehabilitation and reintegration initiatives have seen successful, many governments remain unwilling to invest in this soft approach to the problem. Rehabilitation requires long-term commitment, substantial resources and specially trained personnel (Kohler, 2016). Also, some countries view religion as a private matter although rehabilitation involves far more than religion. While counsellors do preach Islam, content focuses on deradicalization. Reports from different programs indicate that detainees stay refractory to rehabilitation unless all possible reasons for their involvement in violent extremism are properly addressed. Nonetheless, it is impossible to guarantee successful rehabilitation and reintegration for all despite conscientious well-planned implementation. Each detainee took a unique path to radicalization and case officers must address individual anew for each one. 
The countries cited have developed respective strategies to counter terrorism using deradicalization models (Chasdi, 2018). This study identified an optimized approach that can be used globally but only when advantages are integrated within respective indigenous contexts. The authors believe the soft approach can be strategically positioned and introduced as 'preventive and corrective'. Present day challenges are to ensure rehabilitated terrorists are appropriately and responsibly returned to society to contribute to their religion, race and country.

Deradicalization must be pragmatic and dynamic. Those involved in extremism are always in an evolving state and many have developed sophisticated talents for social media and related technology (Gunaratna, 2015). The spread of end-to-end encrypted communications, telegrams, Twitter and virtual private networks (VPNs), as well as dark and deep webs have significantly contributed to this problem. Rehabilitation has to somehow integrate such skills in their programs with methods that are embedded in their modules to ensure program quality and effectiveness. Countries who keep pace with evolving trends have greater success and smaller recidivist rates. Counsellors, Ustaz personnel, prison officers and all involved must be prepared to incorporate technological aspects of rehabilitation.

Some terrorists are naive and know nothing of Islam after having learned what is false through internet and social media. Access to the internet changed the landscape of radicalization by allowing online platforms to facilitate borderless indoctrination programs that also create "lone wolf attackers (Clutterbuck, 2010). Nowadays, there is no need to transport candidates to conflict zones; they need only stay in front of a computer with internet access. Online instructions can match perpetrators to bombings or actions like the Nice truck attacks (2016) and Westminster (2018).

Saudi, Yemen and Malaysia have to be constantly at the ready to confront returning jih adists from Syria, Iraq, Afghanistan and the Caucasus. Most returnees are skilled in guerilla warfare and have attended Maktab al-Khidamah and Firqah special skills classes in combat zones. They learned how to make home-made pipe, Tupperware, phone and watch detonated bombs such as used in the Moovida Nightclub attack in Malaysia and Kuningan bombing by Taufiq Abdul Halim, a Malaysian exiled in Indonesia. Similar attacks by jihadists include Hodaidah, Mukalla and Aden as well as the 2015 car bombing in Sana'a. Saudi Salafism uses Sheikh Muhammad Abdul Wahhab's teachings to mass produce large numbers of terrorists. Scores of attacks have occurred yearly since the 1960s. Many returning jihadi fighters gather to create more chaos and plan attacks in their homelands or other designated jihadi battlefields, including neighboring countries. Any such regrouping has to be monitored as a vital component of police surveillance activities. Nonetheless, the most crucial approach is that of rehabilitation programs once terrorists been lawfully detained.

Prison departments need tailor-made deradicalization programs equipped with experts to handle returning extremists. Malaysia boasts a 95\% success rate for its deradicalization programs compared to Yemen and Saudi. Luxury and leisure marks Saudi-style rehabilitation because Saudis live a comfortable life. Harsh toughness marks prison officers of Yemen's Al-Hitar program which caters to returning jihadists and those involved in the Houthi movement.

Many governments do not pay close attention to legal aspects of enforcement. Countries like Malaysia, Singapore and America have preventive laws like SOSMA, ISA and the Patriot Act. However, most countries have taken no preventive legal measures. Moreover, some countries actually violate preventative laws to achieve political objectives. The UN's Human Rights Office keeps telling Malaysia, Yemen and Saudi to observe human rights rather than their own laws, otherwise all parties participate in abusive practices. Some colonial laws are also unsuitable in today's world and need to be changed. Terrorists inmates subject to such laws have different Page $\mid 7$ 
mindsets and always claim victimization. The right approach taken by prison personnel is vital for the future sake of humanity.

\subsection{CONCLUSION}

The soft approach to counter terrorism with community engagement must be strategically positioned and governments should introduce 'preventive and corrective measures' when addressing violent extremism. Today's challenges also include how to optimally rehabilitate and reintegrate terrorists as part of the community so they best contribute to religion, race and country. The authors identified an optimal approach for global use that can be modified with indigenous advantages suitable for local needs. Saudi Arabia, Yemen and Malaysia have counter terrorist strategies that employ such de-radicalization programs.

Deradicalization can potentially reduce the production of militant propaganda that threatens national and international stability and security, particularly in the ME and Malaysia. Improving extant deradicalization modules is crucial to instill patriotism in former terrorist inmates so they are not revered and emulated by ensuing generations. One must always carefully look into a terrorist's family. If they remain radical, precautionary measures must be taken as there is a strong possibility that other children and adults will become involved. Also, by sharing the experience of former terrorists, awareness of the dangers presented by radicalism is raised and the community can better avoid becoming victimized.

The state is obliged to prevent and combat terrorism while also respecting and protecting human rights. This requires public support. All entities involved in countering violent extremism acknowledge that joint public-private-community partnerships are necessary, particularly in Southeast Asia. There is a growing recognition that the general public are stakeholders and partners rather than passive observers or victims. Authorities in Southeast Asia are developing communityoriented approaches to counter terrorism that emphasize public support and participation with a view to increase accountability and effectiveness. Methods are locally tailored and communitydriven initiatives that draw on partnerships between a wide range of actors that reach beyond traditional security agents and agencies, to include related public authorities as well as civilian organizations, businesses and media.

\section{List of Reference}

Ashour, O. (2015). Deradicalization Revisited. Retrieved on 11 September 2018, from https://www.washingtonpost.com/news/monkey-cage/wp/2015/02/18/deradicalizationrevisited/?utm_term $=$. . $8874 \mathrm{~d} 255762 \mathrm{~d}$

Aslam, M.M. (2009). A Critical Study Of Kumpulan Militant Malaysia, Its Wider Connections In The Region And The Implications Of Radical Islam For The Stability Of Southeast Asia, Ph.D thesis: Victoria University Of Wellington, New Zealand.

Aslam, M.M. (2016). The Threat of D AESH in Malaysian Higher Education Institutions. Kuala Lumpur, MyRISS Special Report to Ministry of Higher Education Malaysia.

Aslam, M.M. (2017). The Threat of Daesh in Universities: Malaysia's Experience. A Journal of the International Centre for Political Violence and Terrorism Research, 9(4), 13-16.

Aslam, M. M. (2018). A Model of Deradicalization in Malaysia. International Case Study of Terrorist Rehabilitation by Rohan Gunaratna \& Sabariah Husin. London, Routledge. 
Chasdi, Richard, J. (2018). Corporate Security Crossroads; Responding to Terrorism Cyberthreats, and Other Hazards in the Global Business Environment. California, Praeger.

Clutterbuck, L. (2010). Deradicalization Programs and Counterterrorism: A Perspective on the Challenges and Benefits. Retrieved on 14 September 2010, from https://www.mei.edu/sites/default/ files/Clutterbuck.pdf

Gunaratna. R, (2015). Countering Violent Extremism: Revisiting Rehabilitation and Community Engagement. Counter Terrorists Trends and Analysis (CTTA), Singapore.

Gunaratna. R, \& Ali, M. (2015). A New Frontier in Counter Terrorism. Imperial College Press Insurgency and Terrorism. Singapore, World Scientific Publishing.

Gunaratna. R, \& Hussin, M.S (2018), International Case Studies of Terrorist Rehabilitation. London, Routledge; Taylor \& Francis Group.

Kohler, D. (2016). Understanding Deradicalization: Methods, Tools and Programs for Countering Violent Extremism. London: Routledge Taylor \& Francis Group.

Neumann, Peter R. (2010). The Trouble With Radicalization. International Affairs Journal, 89(4), 873-893

Noor, S. \& Hayat, S. (2009). Deradicalization: Approaches \& Models. Jakarta, Pak Institute of Peace Studies.

Silber, M. \& Bhatt, A. (2007). Radicalization in the West: Homegrown Threat. Report by Police Department of New York.

Veldhuis, Tinka \& Staun, Jorge. (2009). Islamist Radicalization: A Root Cause Model. The Hague, Netherlands Institute of International Relations Clingendael. 